\title{
Integrating Teaching with Other Aspects of Professorial Work: A Comparison of Experienced and Inexperienced Faculty's Role Conceptualizations
}

\section{CAROLIN KREBER}

University of Alberta

\section{ABSTRACT}

This article reports on a study which investigated the extent to which experienced and inexperienced faculty at Canadian universities integrate their various professorial roles. How faculty conceptualize their work was explored from the perspective of Kelly's (1955) personal construct theory. Experienced faculty were found to integrate the various roles associated with professorial work more strongly than inexperienced faculty. Furthermore, when all activities associated with the teaching role were considered as a single variable, experienced faculty were found to integrate the teaching function more strongly with research and service activities than did their inexperienced peers. Further comparative analyses focussing on specific professorial activities revealed that the two groups showed the highest level of agreement in how they conceptualized the research role, but the highest level of disagreement in how they conceptualized the teaching role. The results of this repertory grid study are discussed in relation to the present culture of higher education that espouses integration of faculty roles as a goal, but at the same time allows only for little opportunity for new faculty to develop the ability to integrate. Some suggestions for the practice of faculty development are offered. 


\section{RÉSUMÉ}

Cet article porte sur une enquête qui consistait à déterminer dans quelle mesure les universitaires canadiens, qu'ils soient expérimentés ou non, intègrent les diverses fonctions liées au professorat. La façon dont les universitaires perçoivent leur travail a été analysée du point de vue de la théorie (Personal Construct Theory) de Kelly (1995). L'étude montre que les universitaires expérimentés intègrent plus facilement les diverses activités liées au professorat que les universitaires non expérimentés. De plus, en considérant l'ensemble des activités liées à l'enseignement comme une variable unique, il s'avère que les universitaires expérimentés intègrent davantage la fonction d'enseignant dans les activités de recherche et de service que les universitaires non expérimentés. Des analyses comparatives plus poussées portant sur des activités du professorat ont révélé que les deux groupes s'accordent le plus quant à la façon dont ils perçoivent le rôle de la recherche, mais sont en radical désaccord quant à la façon dont ils perçoivent le rôle d'enseignant. Les résultats de cette étude sont analysés en prenant en considération la culture actuelle de l'enseignement universitaire qui conçoit l'intégration des fonctions universitaires comme un but, mais qui, toutefois, reconnaît que les nouveaux universitaires ont peu l'occasion de développer la capacité d'intégrer la fonction d'enseignant. Cet article propose quelques suggestions qui contribueraient au développement des pratiques professorales.

\section{INTRODUCTION}

This article reports on a study conducted with a group of eighty-eight faculty members from several Canadian medical/doctoral institutions with the goal of identifying the extent to which they integrate their professorial roles. Specifically, it was examined whether experienced faculty have a more integrated view of professorial work than their inexperienced peers, one that resembles more closely our classical understanding of a close relationship between teaching and research in particular, and perhaps also between the other roles which faculty fulfill. The results of the study are discussed in light of two observations. First, the present culture 
of higher education that expects new faculty to become involved in all aspects of professorial work on the one hand, but which tends to encourage them to concentrate on research on the other. Second, research findings from cognitive and developmental psychology suggesting that integration is an advanced stage of adult development attained through extensive experience over time. Some suggestions for how faculty developers might respond to both observations are also offered.

\section{Describing Professorial Roles}

While exceptions exist, tenure-track faculty, at research-oriented universities, are usually expected to teach well, to be actively involved in the conduct and dissemination of research, and to provide competent service to the institution they work for, as well as to the larger community (Bok, 1982; Cabal, 1993; Goheen, 1969). This tripartite conceptualization of professorial work has a long tradition in higher education.

According to Altbach (1991), teaching has been the defining function of the academic profession since the founding of the early medieval university in the twelfth century. Since the middle of the 19th century, however, the role of faculty no longer focused only on the transmission of knowledge but also on the advancement of knowledge. The idea of the modern research university also meant that universities play a much greater societal role. As a result of the further development of the traditional disciplines as well as the natural and social sciences, the service function was expanded to include the local community, as well as consultation with government and industry (Altbach, 1991). In general, we conceive of professorial work as a combination of teaching, research, and service (for example, Blackburn \& Lawrence, 1995; Bowen \& Schuster, 1986; Braskamp \& Ory, 1994; Buchbinder \& Newson, 1985; Clark, 1987; Finkelstein, 1984; Neatby, 1985). These authors report that faculty work can be broadly categorized as either teaching, research, or service activities, while teaching is sometimes divided into instruction and advising, and service in various forms of institutional governance and community work. Some authors have begun to distinguish scholarship from product research (e.g., Blackburn \& Lawrence, 1995). 
While faculty are currently expected to teach, be actively involved in research, and provide institutional and community service, it has been recently suggested that this traditional conceptualization of professorial work is not reflected in the university reward structure, which places an undue emphasis on refereed publications (e.g., Boyer, 1990; Diamond, 1993; Knapper \& Rogers, 1994; Paulsen \& Feldman, 1995; Rice, 1992; Smith, 1991).

Does the present reward structure promote integration of faculty work? Most Faculty Agreements are very explicit about the tripartite nature of professorial work. Article 7 of the Faculty Agreement of the University of Alberta, for example, states under the heading University Responsibilities, that "a staff member shall be a scholar, active in teaching, in research, and in service" (7.01). While integration of professorial roles may be the intended outcome when new faculty are asked to become involved in all three areas, the result might rather be a fragmentation of professorial roles. What we observe at many campuses is that new faculty are expected to develop a program of research early in their careers. Their involvement in teaching is typically at the undergraduate level with topics that bear little relationship to their research. It is also common to observe new faculty being encouraged to consider being on a "low teaching load," or "buying out" teaching time, so as to increase their opportunity to concentrate on their research. While such offers in and of themselves do not suggest a problem, and to the contrary, seem rather generous, they raise the question of why the reverse option is not open as well, and whether this emphasis on research reflects a fair balance in professorial work.

Being faced with the multifaceted responsibilities of teaching, research, and service on the one hand, and a culture that provides the greatest support and incentives for research productivity on the other, a likely response of new faculty is to concentrate on publishing and bringing in extramural funds so as to be considered excellent researchers. At the same time they try to maintain an acceptable level of performance in teaching and service. This focus on research productivity, however, seems to be quite different from the supposedly "ideal" notion of the scholar who integrates teaching and research, and who distributes his or her efforts more evenly across all domains of professorial work. 


\section{The Myth of Integrating Teaching and Research?}

Is the notion of integration of teaching and research as initiated in the German research university of the nineteenth century a myth as some have argued (Weimer, 1997)? Empirical studies investigating the relationship between these two important strands of faculty work find little or no correlation between the two when the analyses were based on performance outcome measures such as numbers of refereed publications and student ratings of instruction (Braxton, 1996; Feldman, 1987; Hattie \& Marsh, 1996). However, one may question the rationale underlying these investigations on the grounds that the relationship between teaching and research might be more complex than this emphasis on outcome measures suggests. By correlating student perceptions of instructor performance with number of publications, do we not ignore the processes underlying both research and teaching? Could it be in the processes rather than the products where the two might intertwine?

This argument has been made recently by scholars who suggest that a natural synthesis or integration of teaching and research can be observed when university teaching is inquiry-or discovery-based (Clark, 1997; Colbeck, 1998; Rowland, 1996). While they contend that this symbiosis of research and teaching characterizes primarily graduate seminars, the same authors propose such an inquiry ethic as a meaningful way to enhance the quality of undergraduate teaching as well.

Studies also shed some light on how faculty themselves see the relationship between research and teaching. After interviewing twelve professors holding an administrative position as head of their department at a British university, Rowland (1996) concludes "All those interviewed expressed a view that active involvement in the research process directly improved the quality of teaching" (p. 13). It seems worth noting that all twelve participants in Rowland's research had extensive experience as members of the professoriate and had reached the highest professorial rank. A recent U.S. study by Li-Ping Tang and Chamberlain (1997) also raises some interesting questions regarding the role of experience in faculty's perceptions of the relationships between research and teaching. These authors compared administrators' and faculty's attitudes towards teaching and research and report that administrators believe that research 
and teaching are mutually supportive. Faculty, on the other hand, believe that research interferes with teaching, and that they should be required to do either teaching or research, but not both. Interestingly, the sample of faculty consisted of 232 professors at different career stages, with 142 of these being at the rank of assistant and associate professor. Unfortunately, the survey results were not broken down by length of service or professorial rank, so it is unknown whether more experienced faculty might have shared a view of teaching and research that is similar to that of administration. However, the results of Li-Ping Tang and Chamberlain's (1997) and Rowland's (1998) studies indicate a need to further investigate the role of experience in how faculty perceive the relationships between teaching and research. This article reports on a study which investigated whether there are differences between experienced and inexperienced faculty in the extent to which they integrate their various professorial roles. These professorial roles were defined as teaching, research, plus service activities. My main purpose was to explore whether work-related experience may play a role in the development of an increasingly integrated view of professorial work.

In this study, three research questions were addressed. First, are experienced faculty's conceptualizations of professorial work any more integrated than those of inexperienced faculty? Second, do experienced faculty integrate their teaching role to greater extent with the other activities associated with professorial work than inexperienced faculty? Third, what are the specific aspects of professorial work that experienced and inexperienced faculty agree and disagree on the most?

\section{The Notion of Experience in Constructivist Psychology}

Coining the term "man [sic]-the-scientist," Kelly (1955) proposed in his "personal construct theory," that every person, just as a scientist, naturally seeks verification for his or her hypotheses. These hypotheses or "personal constructs" serve as anticipatory schemes for the prediction of events. If the event turns out the way we anticipated, our construct or hypothesis has been confirmed. If, however, the event turns out differently from how we had anticipated, we (have the choice to) revise our construct, and by extension our entire construct system, to predict more accurately next time. 
Through experience, therefore, a person continuously revises his or her conceptualizations or construct system so as to represent more sophisticated conceptual structures, one significant feature of these being their high levels of integration (Adams-Webber, 1995; Bannister, 1960; Bereiter \& Scardamalia, 1993; Ford \& Adams-Webber, 1994; Kelly, 1955).

The domain of experience considered in this study was professorial work in higher education. In line with personal construct theory (Scheer \& Catina, 1993; Kelly, 1955; Neimeyer \& Neimeyer, 1995; Fromm, 1995), the research question was whether faculty, over time, develop a construct system, or implicit personal theory about professorial work, which leads them to integrate their various roles more closely?

In adopting Kelly's (1955) notion of experience to investigate faculty's conceptualizations of professorial work, the notion of "length of service" was distinguished from "active engagement with experience." As the previous discussion shows, it is the latter understanding that underlies personal construct theory. While Kelly's concept of experience presumes considerable length of service, this relationship is not reciprocal. To illustrate this point, Kelly (1955) cites the case of an individual with thirteen years of service by saying "he had only one year of experience - repeated thirteen times" (p. 170). Rather than sampling experienced faculty at random, this study employed purposive sampling, whereby active engagement with the experience of professorial work, in addition to length of service, served as the sampling criteria. This active engagement with professorial work was inferred from two indicators: first, faculty having reached the highest professorial rank and second, these same faculty being the recipient of a university teaching award. It is acknowledged that the former is just one of many possible indicators of active involvement in research, particularly at research universities, and the latter just one of many possible indicators for active involvement in teaching. One further assumption was made, namely that these faculty, over the course of their academic career, also had some involvement in service activities. The inexperienced sample, on the other hand, were faculty in their first two years of a tenure-track appointment. They were considered inexperienced as they had only limited opportunity to involve themselves actively in all aspects of professorial work. 


\section{ACTIVITIES AND CONSTRUCTS ASSOCIATED WITH PROFESSORIAL WORK}

To begin researching the extent to which faculty members integrate their roles, it was necessary to explore how they conceptualize their professorial work experience. Please note that this process has been described previously (Kreber, 2000). To this end, a group of eleven faculty were asked to list all those activities they typically associate with professorial work. This was done during November and December 1995. These professors were from six different Canadian universities. They had been members of the professoriate for at least ten years, had reached the academic rank of full professor and were recipients of a university teaching award. In line with the argument presented earlier, I assumed that these people had some active engagement with the experience of professorial work.

Together this group of faculty generated a list of more than 260 activities in total; however, many activities were stated more than once or overlapped considerably in meaning. A content analysis of this list led to seventeen different activities which faculty associate with professorial work being identified. These are shown in Table 1.

To test the representativeness of these activities several professors of education were asked to review the list. No changes were suggested. The seventeen activities were compared to the higher education literature describing faculty work (for example, Blackburn \& Lawrence, 1995; Bowen \& Schuster, 1986; Braskamp \& Ory, 1994; Braxton \& Toombs, 1980; Buchbinder \& Newson, 1985; Finkelstein, 1984; Clark, 1987). A considerable degree of overlap between the activities mentioned in the literature and those elicited from research participants enhanced confidence in the representativeness of the seventeen activities.

Once the activities faculty typically associate with professorial work had been identified, a group of professors were asked to indicate how they conceptualize these activities. All nine participants in this second phase of the research had reached the highest professorial rank and were recipients of a university teaching award. Data were collected during January and February 1996. To help faculty articulate how they think 


\section{Table 1}

\section{Professorial Activities as Identified by Content Analysis}

A 1. learning about new developments in one's discipline

A 2. counselling students on program and career issues

A 3. off-campus lectures and conference presentations to professional societies

A 4. public talks, consulting, community service

A 5. informal conversations with colleagues

A 6. reviewing and evaluating the work of colleagues (manuscripts, grant proposals, etc)

A 7. formal instruction

A 8. networking with colleagues

A 9. advising/mentoring/assisting colleagues

A 10. conducting research

A 11. preparing for teaching

A 12. writing books, articles, monographs, grant proposals, etc.

A 13. learning about one's teaching

A 14. preparing and conducting evaluations of students' work

A 15. university and departmental committee work

A 16. being a member/participant of professional associations.

A 17. advising students on assignments, projects, and theses

about these activities, Kelly's (1955) triad procedure was followed. Participants were asked to select any three of the seventeen activities from the list, and ask themselves: "In what important way are two of them alike and thereby different from the third?" (Kelly, 1955, p. 222). In response to this question one might say that "conducting research and learning about new developments in one's discipline are both enjoyable whereas these are quite different from preparing and conducting evaluations of students' work, which is not enjoyable. The construct, or way of conceptualizing these activities, thus articulated would be "is enjoyable" versus "is not enjoyable." Each faculty member generated several such 
bipolar constructs, always selecting a different set of three activities from the list. Altogether participants generated a total of 35 bipolar constructs.

Activities and constructs were elicited from experienced faculty only. From the perspective of personal construct theory (Kelly, 1955), people's construct systems change so as to make more accurate predictions as they gain more varied experiences. People with fewer years of experience, therefore, are less likely to have had opportunity to develop the same degree of predictive efficiency (Kelly, 1955) of their construct system. If the goal is to arrive at a list of indicators that are representative of what faculty do, and a list of statements indicating how they conceptualize what they do, it makes sense to gather this information from experienced faculty, rather than inexperienced faculty.

In the third research phase, the meaningfulness or representativeness of these 35 constructs was explored. To this end, the first version of the research instrument to be used in the main research phase was developed. This instrument is also known as a repertory grid.

\section{The Repertory Grid}

As Kelly developed the repertory grid directly on the basis of his original theory (Kelly, 1955), data collected through repertory grids tell us something about the level of integration of a person's construct system. The repertory grid is a two-dimensional matrix representing a person's construct system with respect to a particular domain of experience (Adams-Webber, 1994). In this study the domain of experience considered was professorial work. The grid consists of a series of columns and rows. Each column represented a particular activity associated with professorial work. Each row represented a particular construct used by the person when conceptualizing these activities. The respondent's task is to rate each activity in relation to each bipolar construct listed. Typically, a Likert-scale from 1 to 5 is used, whereby a rating of 1 represents one pole of the construct ("is enjoyable") and a rating of 5 the other ("is not enjoyable").

In its original form, the repertory grid technique was a procedure that included eliciting from respondents a representative sample of both the specific events as well as the abstract constructs that they customarily use 
in order to give meaning to an experience (Kelly, 1955). Over the past forty years, this technique has been altered in many ways, involving the provision of either events or constructs, or both (Scheer \& Catina, 1993; Fromm, 1995; Neimeyer \& Neimeyer, 1995). If the goal is to make comparisons between two groups with regard to their structural features of construing, for instance, the level of integration of their construct system, provided constructs were shown to be comparable to elicited ones (Adams-Webber, 1970; Bannister, 1962; Bannister \& Mair, 1968; Tripodi $\&$ Bieri, 1963).

The first version of the repertory grid used in this study then, consisted of the seventeen professorial activities identified in the first research phase and the 35 bipolar constructs faculty developed in the second phase. To test the validity of the thirty-five constructs, and to select only the most representative constructs for the final research phase, this grid was administered to a group of ten faculty. These ten professors fulfilled the criterion of active engagement in faculty work, as indicated by having reached the highest professorial rank and being the recipient of a teaching award. Participants came from seven different universities. Four of them held appointments with a department of psychology, two with a school of education, and the other four came from physics, biology, management, and political sciences. Data were collected in April 1996.

"Extremity scores" were calculated for each construct, as they were shown to be valid measures of personal meaningfulness, the relative subjective importance of particular constructs (Adams-Webber \& Benjafield, 1973; Bonarius, 1977), and the raters' degree of confidence in the accuracy of their ratings (Hetherington, 1988). The higher the extremity score, the more meaningful the construct is for the respondent. Extremity scores are calculated by looking at how much the score assigned to each activity deviates from the midpoint of the scale. For example, on a five-point scale, if the rating of an activity is 1 , the deviation score will be 2 (3-1). To obtain the extremity score for a particular construct, the deviation scores for each of the seventeen activities are added up and divided by the number of activities. On a scale from 1 to 5, extremity scores can range from 0 to 2 . Once extremity scores were calculated for each of the 35 
constructs for each of the ten grids, mean extremity scores were calculated for all 35 bipolar constructs (Kreber, 2000).

Mean extremity scores for all 35 bipolar constructs ranged from 0.66 to 1.57 . Twenty-three constructs had an extremity scores higher than 1.00 , suggesting that these constructs were considered most meaningful by the ten respondents. Of these twenty-three, five were excluded despite their relatively high score. The construct "teaches me a lot" versus "is not a learning experience" (extremity score of 1.00), for example, was considered to yield more interesting insights than the construct "is public work" versus "is private work" (extremity score of 1.06). Also, the latter was seen to be addressed already by the construct "is solitary" versus "involves others," which had the highest extremity score (1.57). The two constructs "is most rewarding" versus is "less rewarding" (extremity score of 1.04) and "is personally rewarding" versus "is personally unfulfilling" (extremity score of 1.04) were both considered to be very similar to the statement "is satisfying" versus "is not satisfying" (1.08) and the latter was used because it had the higher extremity rating (Kreber, 2000).

In summary, eighteen out of twenty-three bipolar constructs with extremity ratings ranging from 1.00 to 1.57 were selected, while five were dismissed on an intuitive basis. Table 2 shows the eighteen bipolar constructs, with mean extremity scores ranging from 1.00 to 1.57 , which were selected for the final instrument.

In the final research phase, the revised version of the repertory grid was administered. It consisted of seventeen activities and eighteen bipolar constructs, and was given to a sample of experienced and inexperienced faculty to ascertain whether there is a difference in the extent to which the two groups integrate the various aspects of academic work. Data were collected in July, August, and September 1996.

\section{Integrating Professorial Roles}

To limit the effect of institutional and discipline differences as a confounding variable in this study, all faculty participating in the final research phase held appointments with either social science or science departments at medical/doctoral institutions in Canada (Maclean's, November 1997). According to Bowen and Schuster (1986), Clark 
Table 2

\section{Bipolar Constructs Faculty Generated when Conceptualizing the Professorial Activities}

C 6 "is solitary" versus "involves others"

C 18 "involves students" versus "does not involve students"

C 5 "is required" versus "is voluntary"

C 11 "is administratively recorded" versus "is not administratively recorded"

C 13 "is important" versus "is not important"

C 4 "is valuable" versus "is not valuable"

C 8 "wish I could do more of" versus "do enough of"

C 10 "involves learning related to my field of interest" versus "does not involve learning related to my field of interest"

C 7 "I find easy" versus "I find hard"

C 12. "is interesting" versus "is tedious"

C 17 "My doing this is valued by others" versus "My doing this is not valued by others"

C 15 "is satisfying" versus "is not satisfying"
C 9 "involves my use of knowledge in the discipline" versus "involves knowledge that is less discipline-specific"

C 16 "takes a lot of time" versus "takes little time"

C 1 "is enjoyable" versus "is not enjoyable"

C 2 "is creative" versus "is not creative"

C 3 "is intellectually stimulating" versus "is intellectually sterile"

C 14 "teaches me a lot" versus "is not a learning experience" 
(1987), and Finkelstein (1984), the work done by social science faculty and science faculty shares more similarities than any one of them share with the work done by faculty in the humanities and the professional schools. Purposive sampling occurred with the help of Directors of Teaching and Learning Centres at ten different medical/doctoral institutions in Canada, in that Directors were asked to suggest names of faculty in both groups that met the desired criteria.

The Centres suggested 100 subjects for the experienced group and 123 for the inexperienced group. Sixty-seven faculty from the experienced sample and 51 faculty from the inexperienced sample returned the questionnaire, representing a response rate of 66.3 percent and 41.4 percent respectively. Nine questionnaires from the experienced sample were discarded because of missing data and 21 questionnaires from the inexperienced sample were discarded either on the basis of missing data or because the respondents were not on a tenure-track appointment. Altogether 58 useable questionnaires were collected from the experienced sample and 30 from the inexperienced sample representing a real response rate of 57.4 percent and 24.3 percent respectively. The sample distribution is shown in Table 3.

Two thirds of the experienced sample had been full professors for between 5 and 30 years. Their years of experience as a member of the professoriate ranged from ten to more than thirty years. Well over two thirds received their teaching award between 1990 and 1996. Seventy percent of the faculty of the inexperienced sample were in their first year, the others in their second year. More than eighty percent had no prior work experience such as a sessional appointment, and more than half of the sample had never worked as a teaching assistant. However, four of the inexperienced participants were recipients of a teaching award. As might be predicted by the nature of their graduate training, almost all participants had published or presented research prior to their appointment as an assistant professor.

\section{Data analysis}

Each of the eighty-eight grids was analyzed in terms of the level of integration of the construct system of professorial work that it represented. 
Table 3

Sample Distribution in the Final Research Phase

\begin{tabular}{cc}
\hline Experienced & Inexperienced \\
Faculty & Faculty \\
$(\mathrm{N}=58)$ & $(\mathrm{N}=30)$ \\
\hline
\end{tabular}

Institutions

Alberta

British Columbia

9

5

Dalhousie

9

Manitoba

6

McGill

0

McMaster

Ottawa

Queen's

8

6

0

9

Saskatoon

Western Ontario

Disciplines

Biology

Chemistry

5

Chemical Engineering

Computer Sciences

Economics

0

Education

Finance \& Management

Geography

Geology

Health Sciences

Mathematics \& Statistics

\section{1}

2

2

\section{1}

5

1

2

Pharmaceutical Sciences

0

Physical Education

Physics

Politics

Psychology

Sociology

Social Work

Women's Studies

Zoology 
The program used for this purpose was OMNIGRID (Mitterer \& AdamsWebber, 1988) and the statistical measure used was the "average element distance score." This score is calculated by comparing each element (here "professorial activity") with every other in the grid. Each activity is represented by a string of ratings, as many as there are constructs in the grid. In this study, each activity was defined by eighteen ratings as there were eighteen constructs used in the grid task. A particular individual might rate the activity "learning about one's discipline" like this: $1,5,4,4,4,3,2,5,1,1$, $2,2,3,4,5,5,3,3$. This string of ratings represents how that particular activity is conceptualized in terms of the eighteen constructs given (one rating for each construct). OMNIGRID then looks for matching scores between the eighteen ratings assigned to this activity and the eighteen ratings assigned to any other activity in the grid to calculate the distance between them. In other words, OMNIGRID compares the professorial activities in terms of perceived similarity and difference. As a result there were 17(17-1) distance scores, because there were seventeen activities in the grid. Once the distance between each pair of activities in the grid is computed, the "average element distance score" is then calculated. This "average element distance" is an index of the degree to which respondents integrate the activities in terms of the constructs given (Adams-Webber, 1970; Mitterer \& Adams-Webber, 1988). The smaller the score, the more similar the activities are construed, and the greater the level of integration.

Also of interest was whether experienced faculty, compared to inexperienced faculty, integrate their teaching role to a greater extent with the other activities associated with professorial work. To find out, a score was calculated that specifically indicated the degree of integration of all teaching activities with all the others in the grid. It was calculated by recording the "element distance score" (OMNIGRID provided all the inter-element distance scores) from each of the five teaching activities (Activity $7=$ formal instruction, Activity $11=$ preparing for teaching, Activity 13 = learning about one's teaching, Activity $14=$ preparing and conducting evaluations of students' work, and Activity $17=$ advising students on assignments, projects, and theses) with the other twelve activities in the grid. This yielded a total of sixty scores. The mean of these sixty scores was termed the "separation score." It was concluded 
that the lower this score the more integrated the teaching role is perceived to be in relation to the other activities listed in the grid.

Once each grid had been analyzed with respect to "average element distance" (integration of the construct system on the whole) and "separation" (integration of the teaching role with the other activities), group comparisons were made on the basis of these two dependent variables using t-tests for independent groups. The goal was to ascertain whether there are differences in the extent to which the two groups integrate their roles. To answer the third research question, t-tests were conducted on selected grid items.

\section{RESULTS}

Table 4 shows that experienced faculty had a lower element distance score than did their inexperienced peers and this difference was statistically significant at the .05 level $(t=-2.19, p=.031)$. In other words, experienced faculty construed the various professorial activities more similarly. Their conceptualizations (or construct system) of professorial work, as represented by their repertory grid ratings, showed a higher level of integration of the various professorial activities than did those by the inexperienced group.

Table 4 also shows that experienced faculty had a lower separation score than inexperienced faculty $(t=-2.51)$ and this finding was also statistically significant at the .05 level $(p=.014)$. This finding suggests that experienced faculty integrate the teaching role to a greater extent with the other twelve activities listed in the grid than do inexperienced faculty.

The third research question was approached in a more exploratory way. An averaged grid was developed for each group, whereby each cell rating represented the group mean. Each cell can be conceived of as a separate variable. This variable is defined by how the respondent considers a particular professorial activity in relation to a particular construct. Altogether, there were 306 variables in this grid task. Rather than calculating descriptive statistics and t-tests for independent samples for all 306 variables, or randomly selected variables, the two group grids were used to point to obvious areas of disagreement. Those identified areas became 
Table 4

Comparison of Means for Average Element Distances and Separation for Experienced Faculty $(\mathbf{N}=58)$ and Less Experienced Faculty $(\mathbf{N}=\mathbf{3 0})$, 2-tailed t-test

$\begin{array}{llll}M & \text { S.D. } & t & p\end{array}$

Average Element

Distance

$\begin{array}{lllll}\text { experienced } & 7.21 & 0.82 & -2.19 & 0.031 \\ \text { inexperienced } & 7.64 & 0.96 & & \end{array}$

Separation

(Integration of teaching role)

$\begin{array}{lrrrr}\text { experienced } & 7.28 & .86 & -2.51 & 0.014 \\ \text { inexperienced } & 7.81 & 1.03 & & \end{array}$

the focus in further analyses. Specifically, one averaged grid was subtracted from the other, and then, to solve the problem of working with negative numbers, each of the resulting values was squared. Table 5 gives us the squared "difference scores" for each cell as well as the sum of squared "difference scores" for each professorial activity and construct. The greater this score, the greater the difference between the two groups.

With respect to the professorial activities, Table 5 shows that the two groups differed the most on the two teaching activities "formal instruction" (A7) and "preparing for teaching" (A11). The two groups showed the highest level of agreement on the activities "learning about new developments in one's discipline" (A1), "informal conversations with colleagues" (A5), "conducting research" (A10), and "writing books, articles, monographs, and grant proposals"(A12). With the exception of "informal conversations with colleagues" (A5) these are all research activities. Perhaps because of their graduate experience, 
Table 5

Squared Difference Scores for the Averaged Grids of Experienced and Inexperienced Faculty and Sum of Squared "Difference Scores" for each Activity and Construct

\begin{tabular}{|c|c|c|c|c|c|c|c|c|c|c|c|c|c|c|c|c|c|c|}
\hline & $\mathrm{A} 1$ & $\mathrm{~A} 2$ & A3 & A4 & A5 & $A 6$ & $\mathrm{~A} 7$ & A8 & $A 9$ & A10 & A11 & A12 & $\mathrm{A} 13$ & A14 & A15 & $\mathrm{A} 16$ & A17 & \\
\hline & 0.00 & 0.01 & 03 & 0.17 & 0,02 & 0.04 & 0.66 & 02 & 0.02 & 0.00 & 0.44 & 12 & 00 & 0.00 & .07 & .13 & 07 & \\
\hline $\mathrm{C} 2$ & 0.14 & 0.04 & 0.01 & 0.05 & 0.01 & 0.00 & 0.66 & 0.04 & 0.08 & 0.00 & 0.35 & 0.08 & 0.05 & 0.27 & .40 & 0.02 & 0.05 & \\
\hline C 3 & 0.03 & 0.27 & 0.04 & 0.07 & 0.00 & 0.08 & 0.45 & 0.06 & 0.20 & 0.00 & 0.86 & 0.05 & 0.25 & 0.17 & 0.49 & 0.03 & 0.18 & \\
\hline C 4 & 0.00 & 0.31 & 0.00 & 0.00 & 0.00 & 0.13 & 0.40 & 0.01 & 0.10 & 0.00 & 0.13 & 0.02 & 0.00 & 0.58 & 0.48 & 0.00 & 0.14 & \\
\hline C 5 & 0.06 & 0.04 & 0.03 & 0.06 & 0.01 & 0.03 & 0.01 & 0.71 & 0.18 & 0.07 & 0.05 & 0.01 & 0.08 & 0.11 & 0.23 & 0.12 & 0.15 & 1.9 \\
\hline C 6 & 0.18 & 0.26 & 0.01 & 0.03 & 0.03 & 0.01 & 0.42 & 0.00 & 0.07 & 0.28 & 0.00 & 0.18 & 0.27 & 0.01 & 0.02 & 0.13 & 0.01 & 1.9 \\
\hline C7 & 0.00 & 0.94 & 0.01 & 0.01 & 0.00 & 0.06 & 0.22 & 0.07 & 0.24 & 0.04 & 0.08 & 0.02 & 0.32 & 0.21 & 0.17 & 0.22 & 0.49 & \\
\hline C 8 & 0.00 & 0.00 & 2.13 & 0.77 & 0.46 & 0.61 & 0.45 & 1.82 & 0.06 & 0.22 & 0.0 & 0.05 & 0.01 & 0.05 & 0.10 & 0.79 & 0.01 & 7.6 \\
\hline C9 & 0.00 & 0.26 & 0.01 & 0.00 & 0.02 & 0.05 & 0.46 & 0.17 & 0.36 & 0.04 & 0.35 & 0.03 & 0.07 & 0.72 & 0.06 & 0.01 & 0.19 & 2.0 \\
\hline C10 & 0.00 & 0.10 & 0.00 & 0.0 & 0.02 & 0.28 & 0.49 & 0.03 & 0.05 & 0.00 & 0.86 & 0.00 & 25 & 0.53 & 09 & 00 & .58 & \\
\hline C11 & 0.01 & 0.04 & 0.00 & 0.1 & 0.01 & 0.20 & 0.0 & 0.02 & 0.07 & 0.00 & 0.0 & 0.01 & 01 & 0.05 & 4 & 0.61 & 0.32 & 1.5 \\
\hline $\mathrm{C} 12$ & 0.03 & 0.15 & 0.01 & 0.00 & 0.00 & 0.1 & 0.38 & 0.00 & 0.05 & 0.00 & 0.76 & 0.00 & 0.20 & 0.01 & 08 & 0.15 & 0.22 & 2.2 \\
\hline $\mathrm{C} 13$ & 0.00 & 0.12 & 0.09 & 0.04 & 0.00 & 0.00 & 0.03 & 0.02 & 0.10 & 0.02 & 0.02 & 0.01 & 0.00 & 0.19 & 0.34 & 0.00 & 0.37 & 1.3 \\
\hline C14 & 0.03 & 0.14 & 0.05 & 0.03 & 0.01 & 0.01 & 0.07 & 0.01 & 0.04 & 0.00 & 0.30 & 0.08 & 0.00 & 0.01 & 0.01 & 0.00 & 0.03 & 0.8 \\
\hline C15 & 0.00 & 0.03 & 0.01 & 0.05 & 0.06 & 0.09 & 0.32 & 0.01 & 0.01 & 0.01 & 0.50 & 0.01 & 0.06 & 0.00 & 0.05 & 0.07 & 0.04 & 1.3 \\
\hline C16 & 0.02 & 0.02 & 0.00 & 0.02 & 0.03 & 0.00 & 0.03 & 0.01 & 0.02 & 0.08 & 0.06 & 0.00 & 0.10 & 0.00 & 0.01 & 0.05 & 0.03 & 0.4 \\
\hline C17 & 0.00 & 0.31 & 0.01 & 0.04 & 0.04 & 0.03 & 0.15 & 0.12 & 0.27 & 0.01 & 0.22 & 0.01 & 0.01 & 0.36 & 0.16 & 0.12 & 0.13 & 1.99 \\
\hline C18 & 0.22 & 0.03 & 0.34 & 0.17 & 0.00 & 0.02 & 0.00 & 0.10 & 0.04 & 0.10 & 0.03 & 0.31 & 0.05 & 0.17 & 0.48 & 0.02 & 0.00 & 2.07 \\
\hline sum & 75 & 3.07 & 2.79 & 1.64 & 0.73 & 1.78 & 5.26 & 3.21 & 1.97 & 0.88 & 5.09 & 0.89 & 1.74 & 3.45 & 25 & 2.48 & 3.03 & \\
\hline
\end{tabular}


new faculty construe research-related aspects of professorial work similarly to experienced faculty.

With respect to the constructs used in this grid task, Table 5 shows that the two groups disagreed the most on construct eight, "wish I could do more of" (this pole is represented by a rating of 5) versus "do enough of" (this pole is represented by a rating of 1). To identify the specific activities the two groups differed on the most in relation to construct eight, the original 88 grids were revisited, and the individual ratings for construct eight were entered in a SPSS data file. Then, a group comparison of means ( $\mathrm{t}$ test) for each of the seventeen activities rated on construct eight was conducted. Doing a Multivariate Analysis of Variance was not considered meaningful as these seventeen activities were not a traditional set of dependent variables. Table 6 shows that there was a significant difference in how the two groups rated activities A3, A4, A5, A6, A7, A8, A15, and A 16 on this construct. Interestingly, inexperienced faculty felt more strongly than their experienced peers that they "could do more of" the networking and community activities $\mathrm{A} 3, \mathrm{~A} 4, \mathrm{~A} 5, \mathrm{~A} 8, \mathrm{~A} 15$, and $\mathrm{A} 16$. In terms of $\mathrm{A} 7$, "formal instruction," however, they felt more strongly than experienced faculty that they were already "doing enough of" it.

Two other constructs that were considered in this study were constructs three and ten. As for construct three, "is intellectually stimulating" (this pole is represented by a rating of 5) versus "is intellectually sterile" (this pole is represented by a rating of 1), Table 6 shows that there was a significant difference in terms of how the two groups rated activities A2, A7, A9, A11, A15, and A17. On all these activities, which represented teaching and community activities, experienced faculty felt more strongly than inexperienced faculty that these activities are intellectually stimulating. Finally, as for construct ten, "involves learning related to my field of interest" (this pole is represented by a rating of 5) versus "does not involve learning related to my field of interest" (this pole is represented by a rating of 1 ), experienced faculty felt more strongly than inexperienced faculty that activities A6, A7, A11, A14, and A17 involve learning related to their field of interest; and again, most of these activities refer to teaching. Interestingly, on all three constructs, no differences were found in terms of how the two groups rated 
Table 6a

Comparison of Means for Activity Ratings on Construct 3 ( 1 = "is intellectually sterile"; 5 = "intellectually stimulating") for Experienced and Inexperienced Faculty Using the 2-tailed t-test

\begin{tabular}{|c|c|c|c|c|c|c|}
\hline & & \multicolumn{2}{|c|}{$\begin{array}{l}\text { Experienced } \\
\text { Faculty } \\
\mathrm{N}=58 \\
\end{array}$} & \multicolumn{2}{|c|}{$\begin{array}{c}\text { Inexperienced } \\
\text { Faculty } \\
\mathrm{N}=30\end{array}$} & \multirow[b]{2}{*}{$t$-value } \\
\hline & & $M$ & S.D. & $M$ & S.D. & \\
\hline A 1 & $\begin{array}{l}\text { Learning about new develop- } \\
\text { ments in one's discipline }\end{array}$ & 4.65 & 0.60 & 4.83 & 0.46 & -1.41 \\
\hline A 2 & $\begin{array}{l}\text { Counselling students on pro- } \\
\text { gram and career issues }\end{array}$ & 3.18 & 1.06 & 2.66 & 1.02 & $2.21^{*}$ \\
\hline A 3 & $\begin{array}{l}\text { Off-campus lectures and } \\
\text { conference presentations } \\
\text { to professional societies }\end{array}$ & 4.12 & 0.95 & 4.33 & 0.75 & -1.06 \\
\hline A 4 & $\begin{array}{l}\text { Public talks, consulting, } \\
\text { community service }\end{array}$ & 3.67 & 1.01 & 3.40 & 1.07 & 1.17 \\
\hline A 5 & $\begin{array}{l}\text { Informal conversations with } \\
\text { colleagues }\end{array}$ & 3.93 & 0.83 & 3.86 & 1.00 & 0.32 \\
\hline A 6 & $\begin{array}{l}\text { Reviewing and evaluating } \\
\text { the work of colleagues }\end{array}$ & 3.70 & 1.00 & 4.00 & 0.94 & -1.32 \\
\hline A 7 & Formal instruction & 4.39 & 0.69 & 3.73 & 1.01 & $3.60^{* *}$ \\
\hline A 8 & Networking with colleagues & 3.63 & 0.93 & 3.40 & 1.13 & 1.05 \\
\hline A 9 & $\begin{array}{l}\text { Advising / mentoring / } \\
\text { assisting colleagues }\end{array}$ & 3.62 & 0.97 & 3.16 & 0.91 & $2.12^{*}$ \\
\hline A 10 & 0 Conducting research & 4.96 & 0.18 & 4.96 & 0.18 & -0.03 \\
\hline A 11 & 1 Preparing for teaching & 4.53 & 0.59 & 3.60 & 1.07 & $5.26^{* *}$ \\
\hline A 12 & $\begin{array}{l}2 \text { Writing books, articles,mono- } \\
\text { graphs, grant proposals, etc. }\end{array}$ & 4.62 & 0.96 & 4.40 & 0.72 & 1.39 \\
\hline A 13 & 3 Learning about one's teaching & 3.60 & 1.24 & 3.10 & 1.18 & 1.83 \\
\hline A 14 & $\begin{array}{l}4 \text { Preparing and conducting } \\
\text { evaluations of student's work }\end{array}$ & 2.84 & 1.02 & 2.43 & 1.00 & 1.80 \\
\hline A 15 & $\begin{array}{l}5 \text { University and departmental } \\
\text { committee work }\end{array}$ & 2.32 & 0.96 & 1.63 & .076 & $3.43^{* *}$ \\
\hline A 16 & $\begin{array}{l}6 \text { Being a member / participant } \\
\text { of professional associations }\end{array}$ & 2.51 & 1.03 & 2.70 & 1.26 & -0.73 \\
\hline A 17 & $\begin{array}{l}7 \text { Advising students on assign- } \\
\text { ments, projects and theses }\end{array}$ & 4.00 & 0.74 & 3.56 & 1.04 & $2.24^{*}$ \\
\hline
\end{tabular}


Table $6 \mathrm{~b}$

Comparison of Means for Activity Ratings on Construct $8(1=$ "is wish I could do more of"; 5 = "do enough of") for Experienced and Inexperienced Faculty Using the 2-tailed t-test

\begin{tabular}{|c|c|c|c|c|c|c|}
\hline & & \multicolumn{2}{|c|}{$\begin{array}{c}\text { Experienced } \\
\text { Faculty } \\
\mathrm{N}=58 \\
\end{array}$} & \multicolumn{2}{|c|}{$\begin{array}{c}\text { Inexperienced } \\
\text { Faculty } \\
\mathrm{N}=30 \\
\end{array}$} & \multirow[b]{2}{*}{$t$-value } \\
\hline & & $M$ & S.D. & $M$ & $S . D$ & \\
\hline A 1 & $\begin{array}{l}\text { Learning about new develop- } \\
\text { ments in one's discipline }\end{array}$ & 4.24 & 1.04 & 4.26 & 1.11 & -0.11 \\
\hline A 2 & $\begin{array}{l}\text { Counselling students on pro- } \\
\text { gram and career issues }\end{array}$ & 1.98 & 1.27 & 2.00 & 0.98 & -0.06 \\
\hline A 3 & $\begin{array}{l}\text { Off-campus lectures and } \\
\text { conference presentations } \\
\text { to professional societies }\end{array}$ & 2.20 & 1.30 & 3.60 & 1.16 & $-4.91 * *$ \\
\hline A 4 & $\begin{array}{l}\text { Public talks, consulting, } \\
\text { community service }\end{array}$ & 2.24 & 1.26 & 3.06 & 1.33 & $-2.85^{*}$ \\
\hline A 5 & $\begin{array}{l}\text { Informal conversations with } \\
\text { colleagues }\end{array}$ & 2.67 & 1.46 & 3.30 & 1.29 & -1.98 \\
\hline A 6 & $\begin{array}{l}\text { Reviewing and evaluating } \\
\text { the work of colleagues }\end{array}$ & 1.74 & 1.17 & 2.46 & 1.00 & $-2.87^{*}$ \\
\hline A 7 & Formal instruction & 2.24 & 1.39 & 1.50 & 0.82 & $2.68^{*}$ \\
\hline A 8 & Networking with colleagues & 2.34 & 1.41 & 3.63 & 1.35 & $-4.10^{* *}$ \\
\hline A 9 & $\begin{array}{l}\text { Advising / mentoring / } \\
\text { assisting colleagues }\end{array}$ & 2.20 & 1.28 & 2.43 & 1.13 & -0.82 \\
\hline A 10 & Conducting research & 4.00 & 1.27 & 4.46 & 1.07 & -1.72 \\
\hline A 11 & 1 Preparing for teaching & 3.03 & 1.47 & 3.23 & 1.33 & -0.62 \\
\hline & $\begin{array}{l}\text { Writing books, articles, mono- } \\
\text { graphs, grant proposals, etc. }\end{array}$ & 3.81 & 1.19 & 4.03 & 1.24 & -0.82 \\
\hline A 13 & 3 Learning about one's teaching & 2.98 & 1.44 & 3.06 & 1.17 & -0.27 \\
\hline & $\begin{array}{l}4 \text { Preparing and conducting } \\
\text { evaluations of student's work }\end{array}$ & 1.53 & 0.95 & 1.73 & 0.98 & -0.92 \\
\hline & $\begin{array}{l}5 \text { University and departmental } \\
\text { committee work }\end{array}$ & 1.15 & 0.48 & 1.46 & 0.68 & $-2.47^{*}$ \\
\hline & $\begin{array}{l}6 \text { Being a member / participant } \\
\text { of professional associations }\end{array}$ & 1.37 & 0.76 & 2.26 & 1.34 & $-4.00^{* *}$ \\
\hline & $\begin{array}{l}7 \text { Advising students on assign- } \\
\text { ments, projects and theses }\end{array}$ & 2.13 & 1.34 & 2.03 & 1.03 & 0.37 \\
\hline
\end{tabular}

*significant at the .05 level; ${ }^{* *}$ significant at the .001 level

The Canadian Journal of Higher Education

Volume XXX, No. 3, 2000 
Table $6 \mathrm{c}$

Comparison of Means for Activity Ratings on Construct 10 (1 = "does not involve learning related to my field of interest"; 5 = "involves learning related to my field of interest") for Experienced and Inexperienced Faculty Using the 2-tailed t-test

\begin{tabular}{|c|c|c|c|c|c|c|}
\hline \multirow[b]{3}{*}{ A 1} & \multirow[b]{3}{*}{$\begin{array}{l}\text { Learning about new develop- } \\
\text { ments in one's discipline }\end{array}$} & \multicolumn{2}{|c|}{$\begin{array}{l}\text { Experienced } \\
\text { Faculty } \\
\mathrm{N}=58\end{array}$} & \multicolumn{2}{|c|}{$\begin{array}{c}\text { Inexperienced } \\
\text { Faculty } \\
\mathrm{N}=30 \\
\end{array}$} & \multirow[b]{2}{*}{ t-value } \\
\hline & & $M$ & $S . D$. & $M$ & $S . D$. & \\
\hline & & 4.79 & 0.64 & 4.90 & 0.30 & -0.86 \\
\hline A 2 & $\begin{array}{l}\text { Counselling students on pro- } \\
\text { gram and career issues }\end{array}$ & 2.74 & 1.19 & 2.46 & 1.27 & 1.00 \\
\hline A 3 & $\begin{array}{l}\text { Off-campus lectures and } \\
\text { conference presentations } \\
\text { to professional societies }\end{array}$ & 4.25 & 0.90 & 4.30 & 0.79 & -0.21 \\
\hline A 4 & $\begin{array}{l}\text { Public talks, consulting, } \\
\text { community service }\end{array}$ & 3.39 & 1.12 & 3.33 & 1.24 & 0.24 \\
\hline A 5 & $\begin{array}{l}\text { Informal conversations with } \\
\text { colleagues }\end{array}$ & 2.96 & 1.04 & 3.16 & 0.98 & -0.87 \\
\hline A 6 & $\begin{array}{l}\text { Reviewing and evaluating } \\
\text { the work of colleagues }\end{array}$ & 4.34 & 0.82 & 3.89 & 1.07 & $2.31^{*}$ \\
\hline A 7 & Formal instruction & 4.20 & 0.87 & 3.46 & 1.10 & $3.43 * *$ \\
\hline A 8 & Networking with colleagues & 3.24 & 1.06 & 3.13 & 1.10 & 0.45 \\
\hline A 9 & $\begin{array}{l}\text { Advising / mentoring / } \\
\text { assisting colleagues }\end{array}$ & 3.12 & 1.15 & 2.86 & 0.93 & 1.04 \\
\hline A 10 & Conducting research & 4.86 & 0.43 & 4.86 & 0.43 & -0.04 \\
\hline A 11 & Preparing for teaching & 4.29 & 0.83 & 3.33 & 1.21 & $4.35 * *$ \\
\hline A 12 & $\begin{array}{l}\text { Writing books, articles, mono- } \\
\text { graphs, grant proposals, etc. }\end{array}$ & 4.82 & 0.46 & 4.80 & 0.48 & 0.26 \\
\hline A 13 & Learning about one's teaching & 2.92 & 1.41 & 2.41 & 1.22 & 1.69 \\
\hline & $\begin{array}{l}\text { Preparing and conducting } \\
\text { evaluations of student's work }\end{array}$ & 3.20 & 1.30 & 2.53 & 1.22 & $2.34^{*}$ \\
\hline & $\begin{array}{l}\text { University and departmental } \\
\text { committee work }\end{array}$ & 1.72 & 0.87 & 1.36 & 0.80 & 1.86 \\
\hline A 16 & $\begin{array}{l}\text { Being a member / participant } \\
\text { of professional associations }\end{array}$ & 3.29 & 1.25 & 3.30 & 1.44 & -0.02 \\
\hline A 17 & $\begin{array}{l}\text { Advising students on assign- } \\
\text { ments, projects and theses }\end{array}$ & 3.91 & 0.80 & 3.10 & 1.26 & $3.64^{* *}$ \\
\hline
\end{tabular}

*significant at the .05 level; ${ }^{* *}$ significant at the .001 level 
$\mathrm{A} 1, \mathrm{~A} 10$, and $\mathrm{A} 12$, all of them being research activities. On all three constructs, statistically significant differences were found in relation to A7, "formal instruction."

To summarize, a closer look at the data revealed significant differences in how experienced and inexperienced faculty think about the various aspects of professorial work. While the two groups agreed in how they rated the research activities, differences were observed in relation to the teaching and community activities.

The two group grids were also useful in another way. To explore whether experienced and inexperienced faculty differ with respect to how their perception of "meaningfulness" of activities and constructs varies from high to low, a Spearman rank correlation coefficient (Spearman Rho) was calculated for the activity and construct extremity ratings of both groups. In terms of extremity ratings for the seventeen activities, the calculation yielded a Spearman Rho rank order coefficient of $.92(p<.01)$ and in terms of construct extremity one of $.93(p<.01)$. It can be inferred from these results that despite some very interesting differences in how the two groups rated the activities on specific constructs, experienced and inexperienced faculty, overall, agree in terms of the relative importance of the activities and constructs. These high correlations for both activity and construct extremity between the two groups are a strong indicator of the reliability of the grid task.

\section{DISCUSSION}

Experienced faculty were found to integrate the various roles associated with professorial work more strongly than inexperienced faculty. Furthermore, when all activities associated with the teaching role were considered as a single variable, experienced faculty were found to integrate the teaching function more strongly with research and service activities than did their inexperienced peers. The two groups of faculty agreed the most on how they conceptualized the research activities while there was much more disagreement in relation to the other activities listed in the grid. Research was cited earlier that investigated faculty's perceptions of the relationship between teaching and research (Rowland, 
1996; Li-Ping Tang \& Chamberlain, 1997). In this context, I asked the question as to whether it might be that experienced faculty integrate the two important professorial roles more strongly than inexperienced faculty. The results of this study provide some first evidence to support this hypothesis. However, to what extent are these results attributable to work experience rather than to a sampling effect? The experienced group, after all, was purposively selected including only professors who demonstrated competence and interest in teaching, research, and presumably service work.

Would we not expect such special people to integrate their roles well? The cross-sectional nature of the study leaves open to speculation how these experienced faculty might have come to integrate their roles. Furthermore, as the study did not involve data collection from experienced faculty who had not demonstrated competence and interest in either teaching or research, and presumably service, there is no empirical evidence to suggest that the way faculty choose to engage with their experience plays an important role in how well they are able to construe their professorial work. Nevertheless, on a conceptual level it can be argued that engagement with experience fosters integration. Certainly, our experience may also tell us that professors who have been around for some time have more opportunities to better integrate their work. Established faculty teaching only graduate courses on their research interests, and new faculty being assigned courses that are not necessarily in their area of expertise, come to mind immediately. Moreover, we saw earlier that a common message sent to new faculty is to emphasize research over teaching. It needs to be acknowledged, as one possible interpretation of the results of this study, that experienced faculty's greater level of integration in their thinking about professorial roles may also be a matter of opportunity.

Without dismissing this interpretation, an alternative explanation is offered based on findings in cognitive and developmental psychology. In making these connections, the intent is also to provide a rationale for why being able to integrate professorial roles is a desirable attribute, one that goes beyond the arguments already discussed at the beginning of this article (e.g., Clark, 1997, Colbeck, 1998; Rowland, 1996). 
Cognitive science research on the development and nature of expertise shows that expertise is acquired through active engagement with experience, or as Bereiter and Scardamalia (1993) suggest, through "progressive problem-solving" (p. 120). Progressive problem-solving leads to sophisticated cognitive structures which are characterized by greater levels of complexity as well as integration (Bereiter \& Scardamalia, 1993; Glaser and Chi, 1988; Ericsson \& Smith, 1991). According to this view, people who engage in progressive problem-solving continually reinvest the mental resources that have been set free by the process of pattern learning and automatization in problems that are typical for their practice or work domain. The problems or tasks that were shown to be typical for professorial work are listed in Table 1. One may argue that by engaging in progressive problem-solving, or through active involvement with these tasks, faculty develop more advanced ways of conceptualizing and solving the problem, or in other words, more sophisticated cognitive structures about professorial work. Many cognitive psychologists consider expertise the highest stage of cognitive development, recognize integration as an important feature of expertise, and contend that it is acquired through extensive experience over time.

The notion of integration has also been of interest to developmental psychologists. Research in developmental psychology focussing on adult thought patterns has consistently shown a movement from a more fragmented to a more synthesized or integrated conceptualization of issues and world views (Basseches, 1984; King \& Kitchener, 1994; Kramer, 1983, 1989; Labouvie-Vief, 1982; Loevinger, 1976; Perry, 1970). The key to this development is seen, once again, in the nature of the adult learner's experience. On the basis of a review of research on development and adult thinking, Kramer (1983) observes that most models suggest that the highest stage of development implies that "individuals integrate or synthesize contradictions into an overriding more inclusive whole made up of two or more formally consistent systems" (cited in King \& Kitchener, 1993, p. 39). One may speculate that faculty integrate teaching and research (and other aspects of professorial work) over time as they synthesize the contradictions between these roles into a holistic allencompassing and integrated domain of experience: professorial work. 
Both cognitive and developmental psychologists view the ability to integrate as a desirable attribute and contend that is acquired through experience. The assumption underlying this view is that higher levels of integration lead to more sophisticated ways of thinking about issues, and, thus, to more valid conclusions and, eventually, better performance. Is it fair to argue that this ability to integrate is also desirable when considering professorial work?

The present culture of higher education ostensibly values the integration of faculty roles, particularly of teaching and research. However, while new faculty are expected to show involvement in research, teaching, and community work, a message that is typically conveyed is that their real responsibilities rest with the research function while teaching (and service) are necessary add-ons. What on the surface appears to promote integration might in reality lead to a significant differential in the allocation of time and effort spent on research, teaching, and other professorial activities. Considering this reality, as well as the previously cited findings from cognitive and developmental psychology, how meaningful is it to expect faculty to be able to integrate their roles early in their careers?

Such an expectation makes sense only to the extent that new faculty have had the opportunity to gradually increase their specialized knowledge and expertise first in one domain (either teaching or research), then in the other, and, as a result of having acquired further specialization and expertise in each, they develop the ability to integrate the two into the larger experience of professorial work. Such an integration, however, is unlikely to happen in a culture that values research productivity over teaching (Smith, 1991), and thus, allows for little opportunity to develop expertise in teaching. Better integration could occur, if the message sent to new faculty changed from a one-sided "you can buy out teaching time to concentrate on research" to "teaching is just as valuable as research, and can be approached with the same effort and active involvement." Models proposing alternative reward structures, such as the ones suggested by the Carnegie Foundation (Boyer, 1990), the Commission of Inquiry on Canadian University Education (Smith, 1991), and the Contributed Paper for the Task Force of Resource Allocation of the 
Ontario Council of University Affairs (Knapper \& Rogers, 1994), that allow faculty to contract for a specified time period to concentrate on one domain of professorial work, seem particularly worthwhile. Unfortunately, while these recommendations have earned favourable comments on many campuses, to date they appear to have received much less administrative support (Smith, 1997).

Candy (1996) and Brew and Boud (1996) recently proposed approaches to faculty development that are based on this framework. Rather than encouraging integration of professorial roles early in faculty's careers, as has been the widely-advocated view in the faculty development literature over the past several years (e.g., Boice, 1992; Gaff, 1994; Johnston, 1996), Candy, as well as Brew and Boud, promote faculty concentrating on specific roles at different times. Building on their suggestions, as well as the findings of this study, it appears that faculty development, intended to assist faculty in integrating their professorial work over time, should involve providing an institutional climate supportive of faculty developing specialization and expertise first in one area, for example in research or teaching, and then in the other. As faculty gain further experience in each, they also acquire the ability to integrate their various roles in later career stages (Kreber \& Cranton, 2000).

\section{CONCLUSION}

The interpretation of the results of this study is largely speculative. By comparing experienced "all-round competent" faculty to their inexperienced colleagues, and not also to experienced colleagues who did not meet the sampling criteria, the study provides no empirical evidence to support the notion that the way faculty choose to engage with their experience is the key to integration. However, the results do provide evidence that the successful integration of research and teaching, and other aspects of professorial work, may not be a myth. Experienced faculty who, in Kelly's (1955) sense, have had active involvement in professorial work, appear to integrate their various roles better than inexperienced faculty. Nevertheless, further research is needed to verify these findings. Ideally, such studies would be longitudinal as well as cross-sectional, 
and would include a comparison group of experienced faculty that is not predisposed to high integration of professorial roles.

In the meantime, however, these results invite us to reflect on the rationale of espousing integration of professorial roles as a desirable goal on the one hand, while having a reward structure in place that allows little opportunity for new faculty to develop expertise beyond their research role on the other.

\section{References}

Adams-Webber, J.R. (1970). Elicited versus provided constructs in repertory grid technique: A review. British Journal of Medical Psychology, 43, 349-354.

Adams-Webber, J.R. (1979). Personal construct theory. Concepts and applications. New York, NY: John Wiley \& Sons.

Adams-Webber, J.R. (1994). Repertory grid technique. In R. Corsini (Ed.), Encyclopedia of psychology (second edition) (pp. 303-304). New York, NY: John Wiley and Sons.

Adams-Webber, J.R. (1995). Constructivist psychology and knowledge elicitation. Journal of Constructivist Psychology, 8, 237-249.

Adams-Webber, J.R., \& Benjafield, J. (1973). The relation between lexical marking and rating extremity in interpersonal judgment. Canadian Journal of Behavioural Science, 5, 234-241.

Altbach, P.G. (1991). The academic profession. In P.G. Altbach (Ed.), International higher education: An encyclopedia (pp. 23-45). New York, N.Y.: Garland Publishing.

Bannister, D. (1960). Conceptual structure in thought disordered schizophrenics. Journal of Mental Science, 106, 1230-1249.

Bannister, D. (1962). Personal construct theory: A summary and experimental paradigm. Acta Psychologica, 20, 104-120.

Bannister, D., \& Mair, J.M.M. (1968). The evaluation of personal constructs. London: Academic Press.

Basseches, M. (1984). Dialectical thinking and adult development. Norwood, NJ: Ablex.

Bereiter, C., \& Scardamalia, M. (1993). Surpassing ourselves. Chicago and La Salle: Open Court. 
Bieri, J. (1966). Cognitive complexity and personality development. In O.J. Harvey (Ed.), Experience, structure and adaptability. New York, NY: Springer.

Blackburn, R.T., \& Lawrence, J.H. (1995). Faculty at work. Motivation, expectation, satisfaction. Baltimore, MD: The John Hopkins University Press.

Boice, R. (1992). The new faculty member. San Francisco, CA: Jossey-Bass

Bok, D. (1982). Beyond the ivory tower. Social responsibilities of the modern university. Cambridge, MA: Harvard University Press.

Bonarius, J.C.J. (1977). The interaction model of communication: through experimental research toward existential relevance. In J.K. Cole \& A.W. Landfield (Eds.), Nebraska symposium on motivation. Lincoln, NE: University Press.

Bowen, H.R., \& Schuster, J.H. (1986). American professors. A national resource imperiled. New York, NY: Oxford University Press

Boyer, E.L. (1991). Scholarship reconsidered: Priorities of the professoriate. Princeton, NJ: Carnegie Endowment for the Advancement of Teaching.

Braskamp, L.A., \& Ory, J.C. (1994). Assessing faculty work. San Francisco, CA: Jossey-Bass.

Braxton, J.M. (1996). Contrasting perspectives on the relationships between teaching and research. In J.M. Braxton (ed.), Faculty teaching and research: is there a conflict? New Directions for Institutional Research, no. 90, 5-14. San Francisco, CA: Jossey-Bass.

Brew, A., \& Boud, D. (1996). Preparing for new academic roles. The International Journal for Academic Development, 17-26.

Buchbinder, H., \& Newson, J. (1985). The academic work process, the professoriate and unionization. In C. Watson (Ed.), The professoriateoccupation in crisis (pp. 221-247). Toronto, ON: Higher Education Group, The Ontario Institute for Studies in Education.

Cabal, A.B. (1993). The university as an institution today. International Development Research Centre. Paris, FR: UNESCO Publishing.

Candy, P. (1996). Promoting lifelong learning: academic development and the university as a learning organization. The International Journal of Academic Development, 1(1),7-20.

Chi, M., Glaser, R., \& Farr. M. (eds.), The nature of expertise. New Jersey: Erlbaum.

Clark, B. (1997). The modern integration of research activities with teaching and learning. Journal of Higher Education, 68(3), 241-256. 
Clark, B.R. (1987). The academic life. Small worlds, different worlds. Carnegie Foundation for the Advancement of Teaching, Princeton, New Jersey: Princeton New Jersey Press. ERIC Document Reproduction Number ED 299902.

Colbeck, C. (1998). Merging in a seamless blend: How faculty integrate research and teaching. Journal of Higher Education, 96(6), 647-672.

Diamond, R.M. (1993). Changing priorities and the faculty reward system. In R.M. Diamond \& B.E. Adam (Eds.), Recognizing faculty work: reward systems for the year 2000 (pp. 5-13). New Directions for Higher Education, No. 81. San Francisco: Jossey-Bass.

Ericsson ,K.A., \& J. Smith (eds.) (1991). Toward a general theory of expertise. Cambridge, NY: Cambridge University Press.

Feldman, K.A. (1987). Research productivity and scholarly accomplishments of college teachers as related to their instructional effectiveness: A review and exploration. Research in Higher Education, 26(3), 227-298.

Finkelstein, M.J. (1984). The American academic profession. A synthesis of social scientific inquiry since world war II. Columbus, $\mathrm{OH}$ : Ohio State University Press.

Ford, K.M., \& Adams-Webber, J.R. (1994). Knowledge acquisition and constructivist epistemology. In R.R. Hoffman (Ed.), The psychology of expertise (pp.121-136). Mahwah, NY: LEA.

Fromm, M. (1995). Repertory Grid Methodik. Weinheim, Ger: Deutscher Studien Verlag.

Gaff, J. (1994). Faculty development: The new frontier. Liberal Education, $80(4), 16-21$.

Glaser, R., \& Chi, M.T.H. (1988). Overview. In M.T.H. Chi, R. Glaser \& M.J. Farr (Eds.), The nature of expertise (pp. xv-xxviii). Hillsdale, NJ.: Lawrence Erlbaum Associates.

Goheen, R.F. (1969). The human nature of the university. Princeton, NJ: Princeton University Press.

Hattie, J., \& Marsh, H.M. (1996). The relationship between research and teaching: A meta-analysis. Review of Educational Research, 66, 507-542.

Johnston, S. (1997). Preparation for the role of teacher as part of induction into faculty life and work. In P. Cranton (Ed.), Universal challenges in faculty work: Fresh perspectives from around the world. New Directions for Teaching and Learning, no. 72. San Francisco, CA: Jossey-Bass.

Kelly, G.A. (1955). The psychology of personal constructs. Vol 1. A theory of personality. New York, NY: Norton and Company. 
King, P.M., \& Kitchener, K,S. (1994). Developing reflective judgement. San Francisco, CA: Jossey-Bass.

Knapper, C. \& Rogers, P. (1994). Increasing the emphasis on teaching in Ontario Universities. Contributed Paper. Task Force on Resource Allocation. Ontario Council on University Affairs. Toronto, ON.

Kramer, D.A. (1983). Post-formal operations? A need for further conceptualizations. Human Development, 26(2), 91-105.

Kramer, D.A. (1989). The development of an awareness of contradiction across the lifespan and the question of postformal operations. In M.L. Commons, J.D. Sinott, F.A. Richards, and C. Armons (Eds.), Adult Development, Vol 1: Comparisons and applications of developmental models. New York, NY: Praeger Publishing.

Kreber, C. (2000). How teaching award winners conceptualize academic work: Some further thoughts on the meaning of scholarship. Teaching in Higher Education, 5, 61-78.

Kreber, C., \& Cranton, P.A. (2000). Fragmentation versus integration of faculty work. To Improve the Academy, Vol 18, pp. 217-232. The Professional and Organizational Development Network in Higher Education. Bolton, MA: Anker Publishing Com.

Labouvie-Vief, G. (1982). Dynamic development and mature autonomy: A theoretical prologue. Human Development, 25(3), 161-191.

Li-Ping, T., \& Chamberlain, M. (1997). Attitudes towards research and teaching: Differences between administrators and faculty members. Journal of Higher Education, 68(2), 212-228.

Loevinger, J. (1976). Ego development: Conceptions and theories. San Francisco, CA: Jossey-Bass.

Mitterer, J.O., \& Adams-Webber, J.R. (1988). OMNIGRID: a program for the construction, administration and analysis of repertory grids. In J.C. Manusco \& M.L.G. Shaw (Eds.), Cognition and personal structure: computer access and analysis (pp. 89-103). New York, NY: Praeger.

Neatby, B. (1985). The academic profession: an historical perspective. "Communities of scholars in Ontario." In C. Watson (Ed.), The professoriateoccupation in crisis (pp. 10-29). Higher Education Group. The Ontario Institute for Studies in Education.

Neimeyer, R.A., \& Neimeyer, G.J. (Eds.). (1995). Advances in personal construct psychology, Vol. 3. Greenwich, Connecticut: JAI Press. 
Paulsen, M.B., \& Feldman, K.A. (1995). Toward a reconceptualization of scholarship: a human action system with functional imperatives. Journal of Higher Education, 66(6), 615-640.

Perry, W.G. (1970). Forms of intellectual and ethical development in the college years: A scheme. Troy, MO.: Holt, Rinehart \& Winston.

Pope, M., \& Denicolo, P. (1993). The art and science of constructivist research in teacher thinking. Teacher and Teacher Education, 9(5,6), 529-544.

Posner, M.I. (1988). Introduction: What it is to be an expert? In M.T.H. Chi, R. Glaser \& M.J. Farr (Eds.) The nature of expertise (pp.xxixxxxvi). Hillsdale, NJ.: Lawrence Erlbaum Associates.

Rice, R.E. (1991). The new American scholar: scholarship and the purposes of the university. Metropolitan Universities, 1, 7-18.

Rowland, S. (1996). Relationships between teaching and research. Teaching in Higher Education, 1(1), 7-21.

Scheer, J., \& Catina, A.(1993). Einführung in die Repertory Grid-Technik. Band 1: Grundlagen und Methoden. Bern, SW: Verlag Hans Huber.

Smith, S.L. (1991). Report: Commission of Inquiry on Canadian University Education. Ottawa, ON: Association of Universities and Colleges of Canada.

Smith, R.A. (1997). Making teaching count in Canadian Higher Education: Developing a national agenda. Teaching and Learning in Higher Education. Newsletter of the Society for Teaching and Learning in Higher Education (STLHE), 1-10.

Tennant, M., \& Pogson, P. (1995). Learning and change in the adult years. San Francisco, CA: Jossey-Bass.

Tripodi, T., \& Bieri, J. (1963). Cognitive complexity as a function of own and provided constructs. Psychological Reports, 13, 26.

Weimer, M. (1997). Integration of teaching and research: Myth, reality, and possibility. In P. Cranton, (Ed.), Universal challenges in faculty work: Fresh perspectives from around the world. New Directions in Teaching and Learning, no. 72. San Francisco, CA: Jossey-Bass. 